Scientia Agricola

http://dx.doi.org/10.1590/0103-9016-2014-0446

\title{
Resistance mechanisms of sugarcane cultivars to spittlebug Mahanarva fimbriolata
}

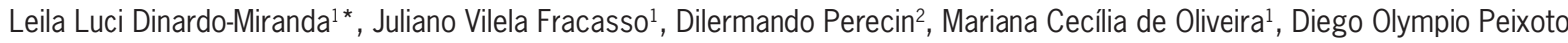 \\ Lopes $^{3}$, Tiago Sabongi Izeppi ${ }^{3}$ Ivan Antonio dos Anjos ${ }^{1}$
}

\begin{abstract}
${ }^{1}$ Agronomic Institute/Sugarcane Center, Rod. Antonio Duarte Nogueira, km 321 - 14001-970 - Ribeirão Preto, SP _ Brazil.

${ }^{2}$ São Paulo State University/FCAV - Mathematical Sciences Dept., Rod. de Acesso Prof. Paulo Donato Castellane, s/n 14884-900 - Jaboticabal, SP - Brazil.

${ }^{3}$ São Paulo State University/FCAV - Plant Protection Dept. *Corresponding author <leiladinardo@iac.sp.gov.br>
\end{abstract}

Edited by: Richard V. Glatz

Received December 24, 2014

Accepted January 04, 2016
ABSTRACT: The spittlebug Mahanarva fimbriolata (Stål) (Hemiptera: Cercopidae) is one of the most important pests of sugarcane in Brazil. Measures for population control are currently restricted to the use of chemical insecticides and fungus Metarhizium anisopliae, in part because very little information exists regarding resistance of sugarcane cultivars. Therefore, the aim of this study was to evaluate resistance mechanisms of 12 different sugarcane cultivars to $M$. fimbriolata to provide information for growers for pest management. Isolated buds of each cultivar were planted in pots and kept in a greenhouse for approximately three months. The pots were then moved to climate test chambers $\left(26 \pm 1^{\circ} \mathrm{C} ; 70 \pm 10 \%\right.$ relative humidity; $12 \mathrm{~h}$ photoperiod) to carry out laboratory tests to evaluate adult feeding and female oviposition preferences (using both free-choice and no-choice tests) as well as the effects of cultivars on nymph development and cultivars tolerance to pest attack. The least attractive cultivars for adult feeding were IACSP96-2042 and IAC91-1099. Cultivars IACSP96-2042, IACSP96-3060 and IACSP94-2101 received the fewest eggs in the free-choice and no-choice oviposition tests and exhibited some level of antixenosis resistance. Cultivar IAC91-1099 showed the highest level of antibiosis resistance with a nymph survival rate in the roots of only $20 \%$. Finally, cultivar IACSP94-2094 appears to be tolerant to M. fimbriolata, as it did not show significant reductions in aboveground biomass weight, despite showing reduced leaf chlorophyll levels following pest attack.

Keywords: Saccharum spp., antixenosis, antibiosis, tolerance

\section{Introduction}

The spittlebug Mahanarva fimbriolata (Stål) (Hemiptera: Cercopidae) is a major sugarcane pest in Brazil, causing yield loss up to $50 \%$ and affecting sugarcane quality by reducing stalk sugar levels and increasing fiber content (Dinardo-Miranda et al., 1999; 2001; 2002). Furthermore, sugarcane industrial processes are also affected by $M$. fimbriolata, as damaged stalks can reduce milling capacity. In particular, cracked and deteriorated stalks lead to increased levels of contaminants, hindering sugar recovery and inhibiting fermentation (Madaleno et al., 2008).

Due to the importance of this insect to sugarcane growers, a number of studies have been conducted to establish parameters for integrated pest management (IPM) programs. Recent studies have been conducted to estimate the economic injury level (Dinardo-Miranda and Gil, 2007; Dinardo-Miranda et al., 2008), to determine the temporal and spatial distribution of the pest in sugarcane fields (Dinardo-Miranda et al., 2007) and to evaluate the efficacy of chemical and biological insecticides (Dinardo-Miranda et al., 2002; 2004) or cultural practices against the pest (Dinardo-Miranda and Fracasso, 2013). However, information on resistance of sugarcane cultivars to $M$. fimbriolata is very limited.

Dinardo-Miranda et al. (1999; 2001) evaluated spittlebug populations and damage caused by them under field conditions using a number of sugarcane genotypes. The authors observed significant differences in resistance between the cultivars. For example, genotypes IAC83-2396, SP80-1842 and RB825336 were severely at- tacked by $M$. fimbriolata and were preferred by the pest over other cultivars, leading to considerable yield loss. However, the researchers reported that even the least effected cultivars, such as IAC82-3092, IAC87-3197 and PO86-1107, also showed significant yield reductions due to $M$. fimbriolata infestation.

Although there is little information available about the effects of spittlebugs on specific sugarcane genotypes, these findings are crucial for choosing appropriate resistant cultivars to be used in IPM strategies. In addition, resistant genotypes are invaluable for breeding programs aimed at developing new resistant cultivars. Therefore, the objective of this study was to evaluate the resistance mechanisms of various sugarcane genotypes (obtained from the IAC Sugarcane Breeding Program) to M. fimbriolata attack.

\section{Materials and Methods}

The experiments were conducted in Ribeirão Preto, São Paulo State, Brazil $\left(21^{\circ} 12^{\prime} 56^{\prime \prime} \mathrm{S}\right.$ and $47^{\circ} 52^{\prime} 38^{\prime \prime}$ W, altitude $630 \mathrm{~m}$ ) between November 2011 and March 2013 under laboratory conditions (room at $26 \pm 1{ }^{\circ} \mathrm{C} ; 70$ $\pm 10 \% \mathrm{RH} ; 12 \mathrm{~h}$ photoperiod).

The following 12 cultivars were evaluated in these experiments: IAC87-3396, IAC91-1099, IACSP93-3046, IACSP94-2094, IACSP94-2101, IACSP94-4004, IACSP95-1218, IACSP95-3028, IACSP95-5000, IACSP96-2042, IACSP96-3060 and SP81-3250. Cultivar SP81-3250 was chosen as a susceptible reference cultivar (Dinardo-Miranda et al., 2001) that is widely cultivated in São Paulo State, Brazil, and the others were chosen 
because they were in selection final phase of the Sugarcane Inbreeding Program of Agronomic Institute (IAC).

Pots (1-Liter) were used to study the attractiveness of sugarcane plants to $M$. fimbriolata adults and to determine their oviposition preferences under free-choice and no-choice conditions. For the tolerance studies, 5-L pots were used. All pots were filled with a mixture of clay soil and agricultural substrate $(1: 1)$ and treated with a slow-release fertilizer (14-14-14, NPK; $200 \mathrm{~g}$ in $25 \mathrm{~kg}$ soil + substrate).

One bud of a given cultivar was planted in each pot. The pots were kept for approximately 60 days in a greenhouse favorable to sugarcane growth. The pots were then transported to the laboratory for testing.

The spittlebug populations used in all of reported experiments were obtained from a laboratory stock colony at the Sugarcane Center of the Agronomic Institute (Instituto Agronômico - IAC) that was reared on SP801842 sugarcane cultivar according to the technique described by Garcia et al. (2007).

To investigate the attractiveness of sugarcane cultivars to adult $M$. fimbriolata, five pots for each of the 12 cultivars (60 total) were randomly placed around the perimeter of a circle in a climate test room (carried out on $27 \mathrm{Dec}, 2012$ ), yielding a randomized experimental design with five replicates. Next, 150 paired male and female spittlebugs were released in the center of the room and the number of adults on the stalks and leaves of each plant were counted 0.5, 1, 6, 12, 96 and 120 hours after release. For the statistical analysis, the count data (insects) were transformed by the square root of $(x+1)$, subjected to the analysis of variance and the means were compared using the $t$ test. Initially, each assessment (counting after release) was analyzed separately as a randomized experimental design with five replicates. Subsequently, it was used a mixed-model with a fixed assessment effect and a random "within assessment-cultivar effect", considering the effects of cultivar, assessment and cultivar $\times$ assessment interaction.

To determine the cultivars preferred by females M. fimbriolata for oviposition under free-choice conditions, five pots of each of the 12 studied cultivars were placed randomly in a circle, as described above. This test was repeated three times (tests 1,2 and 3). Prior to insect release, a cotton layer was placed on the soil surface around the base of each plant to catch the eggs laid by females. Spittlebug couples were released immediately following an arrangement of the pots. Since the duration of the embryonic development ranges from 18 to 21 days (Garcia et al., 2006), ten days after the release, the cotton layers from each pot were removed and labeled and all eggs were counted. Next, 50 eggs from each plant were selected and placed on a filter paper in Petri dishes. Samples were kept under moist BOD (biochemical oxygen demand) conditions at temperature $26 \pm 1{ }^{\circ} \mathrm{C}$ with a $12 \mathrm{~h}$ photoperiod. Newly hatched nymphs were counted daily to determine egg viability. Test 1 began on Dec 13, 2012 with the release of 150 spittlebug couples; test 2 began on Dec 27, 2012 with the release of 100 couples, and test 3 began on Jan 02, 2013 with the release of 137 couples. For the statistical analysis, the count data were transformed by the square root of $(x+1)$ and the percentage data by the arcsine of the square root of $(x / 100)$. All data were subjected to the analysis of variance and the means were compared using the t test. Initially, the three tests were analyzed separately as a randomized experimental design with five replicates. Subsequently, it was used a mixed-model with a fixed test effect and a random "within test-cultivar effect". These analyses were performed for both parameters studied: eggs found in each cultivar and egg viability.

To determine oviposition preferences of M. fimbriolata females in a no-choice test, seven pots of each cultivar were arranged in a climate test room. A cotton layer was placed on the soil surface at the base of each plant to catch the eggs laid by the females. Then, each pot was placed under a wooden cage $(100 \mathrm{~cm}$ height $\times$ $20 \mathrm{~cm}$ diameter) with sides made of nylon-screen material (approximately 1-mm mesh size) where three newly hatched spittlebug couples were released. The test was concluded ten days after release, when the cotton layers from each pot were removed and labeled and the eggs were counted. Next, 50 eggs from each plant were selected and placed on filter paper in Petri dishes. Samples were kept under moist BOD conditions at temperature $26 \pm 1{ }^{\circ} \mathrm{C}$ with a $12 \mathrm{~h}$ photoperiod. Newly hatched nymphs were counted daily to determine egg viability. Due to the difficulty in obtaining sufficient numbers of insects for simultaneous release, spittlebug couples were released on different dates for each replicate. Therefore, the experiment was carried out using a randomizedblock statistical design with seven replicates. $M$. fimbriolata couples were released for replicates 1 through 7 on Jan 14, 2013; Jan 18, 2013; Jan 21, 2013; Jan 22, 2013; Jan 23, 2013; Jan 28, 2013 and Jan 30, 2013, respectively. For the statistical analysis, the count data were transformed by the square root of $(x+1)$ and the percentage data by the arcsine of the square root of $(x / 100)$. All data were subjected to the analysis of variance and the means were compared using the $t$ test.

The effects of the various sugarcane cultivars on nymph development were evaluated using a randomized design with twelve treatments (cultivars) and five replicates. On Feb 7, 2012, plants approximately 60-day-old were carefully uprooted, exposing a portion of the roots and placed in plastic dishes. Due to good root development, the soil + substrate mixture remained in clumps, encased by the plant roots. Next, ten newly hatched nymphs were applied to the roots of each plant using a fine bristle brush. Following infestation, the plants were kept under wooden cages $(100 \mathrm{~cm}$ height $\times 20 \mathrm{~cm}$ diameter) with nylon-screen sides (approximately 1-mm mesh size) to prevent the escape of emerged adults. Plants were inspected daily and any emerged adults were counted and removed. Plants that were depleted due to pest attack were replaced with others of the same 
cultivar (kept until that point in a greenhouse) to ensure that plant death did not interfere with nymph survival. On such occasions, any nymphs that remained on the depleted plants were carefully transferred to healthy plants using a brush, along with the foam produced by their feeding. After test completion, the survival rate for each pot (plot) and the durations of the nymph stages were determined. The survival rate of each pot was estimated by dividing the number of emerged adults by the number of infested nymphs (10), multiplied by 100 . For the statistical analysis, the percentage data (nymph survival) were transformed by the square root of $(x+1)$. For both parameters, initially, the data were subjected to the analysis of variance, considering a randomized design with 12 treatments (cultivars) and five replicates. The means were compared using the test. Subsequently, a mixed-model was used.

The spittlebug multiplication rate (MR) for each cultivar was calculated based on the number of eggs laid by the three females (NE) during the free-choice oviposition preference test, egg viability (EV), nymph survival (NS) and sex ratio of 0.5 (Garcia et al., 2006). The equation $\mathrm{MR}=\mathrm{NC} 1 / \mathrm{NC} 0$ was used, where $\mathrm{NC} 1=$ the number of couples in generation $1 ; \mathrm{NCO}=$ the number of couples in the initial generation (3); and $\mathrm{NC1}=\mathrm{NE}$ (EV/100) (NS/100) 0.5.

To evaluate cultivar tolerance to nymph development, 12 plants from each cultivar were carefully uprooted, exposing a portion of their roots. Again, due to good root development, the soil + substrate mixture remained in clumps, encased by the plant roots. Plants were then placed on plastic dishes and transported to the laboratory for testing on Nov 9, 2011. In the laboratory, six plants from each cultivar were each infested with six newly hatched spittlebug nymphs, which were transferred to the roots with the aid of a brush. Six plants were not infested and were used as a control group. The experiment was carried out using a completely randomized design with six replicates. Treatments were arranged in a factorial design $(12 \times 2)$ with one of the factors representing the cultivars (12) and the other representing the presence or absence of spittlebug infestation (2). After infestation, the plants were kept under wooden cages $(100 \mathrm{~cm}$ height $\times 20 \mathrm{~cm}$ diameter) with nylon-screen sides (approximately 1-mm mesh size) to prevent the escape of emerged adults. The uninfested plants were also kept in cages to maintain the same conditions in all pots. Infested plants were inspected weekly. When needed, plants were infested with newly hatched nymphs so that each plant remained infested with six nymphs during the trial period. Thirty days after the first infestation, chlorophyll content in the leaves of each plant was estimated using a portable chlorophyll meter. Measurements were performed in the middle of the +1 leaf from each plant. All measurements were performed in duplicate and the average was used in the statistical analyses. At the same time, the shoots of all plants were cut at soil level and weighed. For chlorophyll content and weight data, the analysis of variance was performed considering the effect of cultivar, infestation and cultivar $x$ infestation interaction, since the treatments were arranged in a factorial design $(12 \times 2)$ with 12 cultivars and two spittlebug infestations. With the data obtained on infested and non-infested plant, the percent reduction of aboveground biomass and the percent reduction of chlorophyll content, caused by spittlebug infestations in each cultivar, were calculated. These data were transformed by the arcsine of the square root of $(x / 100)$ and the analysis of variance was performed considering a randomized-block design with six replicates. The means were compared using the $t$ test.

All statistical analyses were performed using the SAS software program (Statistical Analysis System, version 8.1).

\section{Results and Discussion}

In experiments testing the attractiveness of various sugarcane cultivars to adult $M$. fimbriolata, many individuals sought shelter between plant leaves immediately after release, whereas other insects remained on the floor or walls of the climate test room. During the first evaluation, a half hour after the release of insect couples, $25 \%$ of the adults had already reached the plants and were found feeding, breeding, walking or resting among the leaves. At later evaluations, $35 \%$ (6-hour post-release) and $34 \%$ (120-hour post-release) of the insects were found on plants, values statistically similar (Table 1).

Considering each assessment separately, there was no significant difference among cultivars. However, a characterization of cultivar attractiveness to adults was performed by combining the data from all six assessments, which revealed significant differences among them. On average, cultivars IACSP96-2042 $10.8 \pm 0.2$ adults per plant) and IAC91-1099 (0.9 \pm 0.5 adults per plant) were the least attractive to adults, whereas cultivar IACSP94-4004 (2.3 \pm 0.6 adults per plant) was the most attractive. Cultivar SP81-3250, which was used as a standard for susceptibility, attracted an intermediate number of adults (1.6 \pm 0.3 adults per plant), a value that was statistically similar to those for the other cultivars. The interaction cultivar $\times$ assessment was not significant with respect to adult attractiveness (Table 1). Genotypic differences in the attractiveness of plant cultivars to adult spittlebugs have also been reported by Shortman et al. (2002), who carried out experiments using 56 different turfgrass genotypes and the two-lined spittlebug Prosapia bicincta (Say) (Hemiptera; Cercopidae).

In the free-choice oviposition preference studies, significant differences between cultivars regarding the number of eggs laid by females were observed in the three tests. In the three tests, cultivars that received more eggs varied, but in two of them, cultivar IACSP96-2042 received the least eggs (Table 2). The mixed-model analysis showed that the interaction cultivar $\times$ test was 
Table 1 - Numbers of Mahanarva fimbriolata adults found on each plant at different time points after release.

\begin{tabular}{|c|c|c|c|c|c|c|c|}
\hline \multirow{2}{*}{ Cultivar } & \multicolumn{7}{|c|}{ Assessment period (hours after release) } \\
\hline & 0.5 & 1 & 6 & 12 & 96 & 120 & mean \\
\hline IACSP96-2042 & $0.6 \pm 0.3 a$ & $0.4 \pm 0.2 \mathrm{a}$ & $1.6 \pm 0.5 \mathrm{a}$ & $0.6 \pm 0.2 \mathrm{a}$ & $1.2 \pm 0.4 \mathrm{a}$ & $0.6 \pm 0.2 \mathrm{a}$ & $0.8 \pm 0.2 \mathrm{a}$ \\
\hline IAC91-1099 & $0.8 \pm 0.5 a$ & $1.4 \pm 0.9 \mathrm{a}$ & $1.4 \pm 0.9 a$ & $0.4 \pm 0.2 \mathrm{a}$ & $0.4 \pm 0.4 \mathrm{a}$ & $1.2 \pm 0.5 \mathrm{a}$ & $0.9 \pm 0.5 a$ \\
\hline IACSP95-5000 & $1.0 \pm 0.4 \mathrm{a}$ & $0.6 \pm 0.4 a$ & $1.4 \pm 0.4 \mathrm{a}$ & $1.0 \pm 0.2 \mathrm{a}$ & $0.8 \pm 0.5 \mathrm{a}$ & $1.4 \pm 0.5 \mathrm{a}$ & $1.0 \pm 0.5 \mathrm{ab}$ \\
\hline IAC87-3396 & $1.6 \pm 0.8 \mathrm{a}$ & $1.4 \pm 0.5 \mathrm{a}$ & $1.2 \pm 0.2 \mathrm{a}$ & $0.6 \pm 0.2 \mathrm{a}$ & $0.6 \pm 0.4 a$ & $1.0 \pm 0.3 \mathrm{a}$ & $1.1 \pm 0.3 \mathrm{ab}$ \\
\hline IACSP93-3046 & $0.6 \pm 0.4 a$ & $0.4 \pm 0.4 a$ & $1.4 \pm 0.7 \mathrm{a}$ & $1.0 \pm 0.6 \mathrm{a}$ & $1.6 \pm 0.5 \mathrm{a}$ & $1.4 \pm 0.7 \mathrm{a}$ & $1.1 \pm 0.4 \mathrm{ab}$ \\
\hline IACSP96-3060 & $0.6 \pm 0.5 a$ & $1.0 \pm 0.4 \mathrm{a}$ & $2.2 \pm 0.4 \mathrm{a}$ & $1.0 \pm 0.4 a$ & $1.4 \pm 0.5 \mathrm{a}$ & $2.0 \pm 0.5 \mathrm{a}$ & $1.4 \pm 0.3 \mathrm{ab}$ \\
\hline SP81-3250 & $1.2 \pm 0.4 \mathrm{a}$ & $1.0 \pm 0.5 \mathrm{a}$ & $2.2 \pm 0.7 a$ & $1.8 \pm 0.3 a$ & $2.4 \pm 0.6 \mathrm{a}$ & $1.2 \pm 0.5 \mathrm{a}$ & $1.6 \pm 0.3 a b$ \\
\hline IACSP95-1218 & $1.2 \pm 0.5 \mathrm{a}$ & $3.0 \pm 0.4 \mathrm{a}$ & $1.2 \pm 0.5 \mathrm{a}$ & $1.4 \pm 0.7 \mathrm{a}$ & $1.6 \pm 0.5 \mathrm{a}$ & $2.2 \pm 0.6 a$ & $1.8 \pm 0.3 a b$ \\
\hline IACSP95-3028 & $1.2 \pm 0.3 a$ & $1.4 \pm 0.5 \mathrm{a}$ & $2.4 \pm 0.7 a$ & $2.6 \pm 0.6 a$ & $2.0 \pm 0.4 a$ & $2.2 \pm 0.5 \mathrm{a}$ & $2.0 \pm 0.3 \mathrm{ab}$ \\
\hline IACSP94-2101 & $2.0 \pm 0.8 a$ & $1.6 \pm 0.6 a$ & $1.2 \pm 0.5 \mathrm{a}$ & $1.4 \pm 0.5 \mathrm{a}$ & $3.6 \pm 1.0 \mathrm{a}$ & $2.6 \pm 0.8 a$ & $2.1 \pm 0.5 \mathrm{ab}$ \\
\hline IACSP94-2094 & $1.8 \pm 0.8 \mathrm{a}$ & $2.0 \pm 0.7 a$ & $1.8 \pm 0.8 \mathrm{a}$ & $2.8 \pm 1.1 \mathrm{a}$ & $1.8 \pm 1.0 \mathrm{a}$ & $3.0 \pm 1.1 \mathrm{a}$ & $2.2 \pm 0.6 \mathrm{ab}$ \\
\hline IACSP94-4004 & $2.2 \pm 0.9 a$ & $3.6 \pm 1.2 \mathrm{a}$ & $3.0 \pm 1.0 \mathrm{a}$ & $2.0 \pm 0.8 \mathrm{a}$ & $1.8 \pm 0.9 \mathrm{a}$ & $1.4 \pm 0.4 \mathrm{a}$ & $2.3 \pm 0.6 b$ \\
\hline \multicolumn{8}{|c|}{$\bar{F}$ values (degree of freedom) } \\
\hline Cultivar & $0.72^{\text {NS }}(11)$ & $1.76^{\mathrm{NS}}(11)$ & $0.68^{\mathrm{NS}}(11)$ & $1.52^{\mathrm{NS}}(11)$ & $1.66^{\mathrm{NS}}(11)$ & $0.96^{\mathrm{NS}}(11)$ & $5.17^{* *}(11)$ \\
\hline Assessment & - & - & - & - & - & - & $1.53^{\mathrm{NS}}(5)$ \\
\hline Cultivar $\times$ assessment & - & - & - & - & - & - & $1.52^{\mathrm{NS}}(55)$ \\
\hline CV (\%) & 31 & 32 & 29 & 29 & 29 & 29 & 25 \\
\hline
\end{tabular}

Means in the same column followed by the same letter do not differ significantly (t test, $p<0.05$ ); NS and ${ }^{* *}$ indicate values not significant and significant at $p \leq$ 0.01 respectively.

Table 2 - Numbers of Mahanarva fimbriolata eggs found on each cultivar in the free-choice tests.

\begin{tabular}{lcccc}
\hline \multirow{2}{*}{ Cultivar } & \multicolumn{4}{c}{ Eggs per plot } \\
\cline { 2 - 5 } & test 1 & test 2 & test 3 & mean \\
\hline IACSP96-2042 & $43.8 \pm 13.0 \mathrm{a}$ & $85.6 \pm 20.0 \mathrm{ab}$ & $37.2 \pm 9.1 \mathrm{a}$ & $55.5 \pm 11.9 \mathrm{a}$ \\
IACSP96-3060 & $45.6 \pm 8.6 \mathrm{ab}$ & $107.0 \pm 19.4 \mathrm{abc}$ & $70.4 \pm 20.3 \mathrm{abc}$ & $74.3 \pm 11.2 \mathrm{ab}$ \\
IACSP94-2101 & $108.0 \pm 22.9 \mathrm{~b}$ & $74.4 \pm 12.1 \mathrm{a}$ & $49.6 \pm 12.7 \mathrm{ab}$ & $77.3 \pm 10.9 \mathrm{ab}$ \\
IAC91-1099 & $75.6 \pm 18.9 \mathrm{ab}$ & $78.8 \pm 22.7 \mathrm{a}$ & $101.4 \pm 37.1 \mathrm{abc}$ & $85.3 \pm 20.9 \mathrm{ab}$ \\
IAC87-3396 & $56.4 \pm 17.1 \mathrm{ab}$ & $119.2 \pm 17.5 \mathrm{bcd}$ & $114.6 \pm 34.1 \mathrm{abc}$ & $96.7 \pm 19.8 \mathrm{bc}$ \\
IACSP95-5000 & $99.4 \pm 21.8 \mathrm{~b}$ & $100.0 \pm 31.8 \mathrm{abc}$ & $100.6 \pm 39.6 \mathrm{abc}$ & $100.0 \pm 23.2 \mathrm{bc}$ \\
IACSP93-3046 & $85.6 \pm 22.3 \mathrm{ab}$ & $87.8 \pm 16.1 \mathrm{abc}$ & $151.4 \pm 29.9 \mathrm{c}$ & $108.3 \pm 14.9 \mathrm{c}$ \\
IACSP95-3028 & $66.0 \pm 17.7 \mathrm{ab}$ & $144.0 \pm 20.3 \mathrm{bcd}$ & $137.6 \pm 27.5 \mathrm{c}$ & $115.9 \pm 15.1 \mathrm{c}$ \\
IACSP94-4004 & $54.4 \pm 11.5 \mathrm{ab}$ & $136.2 \pm 8.8 \mathrm{bcd}$ & $160.4 \pm 46.6 \mathrm{c}$ & $117.0 \pm 24.3 \mathrm{c}$ \\
SP81-3250 & $78.0 \pm 18.6 \mathrm{ab}$ & $112.4 \pm 37.0 \mathrm{abc}$ & $162.8 \pm 44.4 \mathrm{c}$ & $117.7 \pm 20.9 \mathrm{c}$ \\
IACSP94-2094 & $120.2 \pm 38.7 \mathrm{~b}$ & $186.8 \pm 33.7 \mathrm{~cd}$ & $80.2 \pm 17.1 \mathrm{abc}$ & $129.1 \pm 20.4 \mathrm{c}$ \\
IACSP95-1218 & $57.4 \pm 13.6 \mathrm{ab}$ & $232.8 \pm 35.2 \mathrm{~d}$ & $120.6 \pm 33.7 \mathrm{bc}$ & $136.9 \pm 24.9 \mathrm{c}$ \\
\hline F values (degree of freedom) & & & & \\
Cultivar & $2.29^{*}(11)$ & $2.88^{*}(11)$ & $2.68^{*}(11)$ & $2.80^{* *}(11)$ \\
Test & - & & & $4.03^{* *}(2)$ \\
Cultivar $\times$ test & - & 18 & $1.74^{*}(22)$ \\
\hline CV (\%) & 14 & & 16 \\
\hline
\end{tabular}

Means in the same column followed by same letter do not differ significantly (t test, $p<0.05$ ); NS, ${ }^{*}$ and ${ }^{*}$ indicate values not significant, significant at $p \leq 0.05$ and significant at $p \leq 0.01$ respectively.

significant only for IAC91-1099 $(F=4.83, p=0.0093)$ and IACSP95-1218 ( $F=4.75, p=0.0101)$ cultivars. For these cultivars, the expected value was different from the obtained value, while for all others cultivars, the interaction was not significant. When the mean values of all three tests were calculated, cultivars IACSP96-3060 and IACSP96-2042 received the least eggs, whereas cultivars IACSP95-1218, IACSP94-2094, SP81-3250, IACSP94-4004, IACSP95-3028, IACSP93-3046, IACSP95-5000 and IAC87-3396 appeared to be preferred for oviposi- tion. Cultivars IACSP94-2101 and IAC91-1099, which received the least eggs during test 2 , presented as one of the least preferred cultivars when all three tests were averaged. Auad et al. (2007) also reported genotypic differences in the attractiveness of elephant grass cultivars to egg-laying females of the spittlebug Mahanarva spectabilis (Distant, 1909) (Hemiptera; Cercopidae).

In general, the results for oviposition preference under free-choice conditions were similar to those for adult attractiveness. During the adult-attractiveness 
tests, cultivar IACSP96-2042 sheltered the smallest number of adults and also received the least eggs in the freechoice test of all cultivars. Similarly, cultivar IAC91-1099 was among the least attractive cultivars for food and shelter and also received the smallest number of eggs, although this was not significantly different from the other cultivars. Conversely, IACSP94-4004, IACSP94-2094, IACSP95-3028 and IACSP95-1218 were among the most preferred cultivars for both feeding and shelter, which was also observed for oviposition. These data indicate that adult $M$. fimbriolata feed and shelter more frequently in the cultivars that they prefer for egg laying.

Consistent with the findings of the present study, a correlation between adult attractiveness and oviposition preference has also been observed in a number of different insect species. For example, such a correlation was found for pest species Bemisia tabaci (Genn.) biotype B (Hemiptera: Aleyrodidae) on different soybean (Valle and Lourenção, 2002), bean (Oriani et al., 2005) and cowpea genotypes (Cruz et al., 2012).

No significant differences in egg viability (Table 3) were observed between the cultivars in any of the tests performed, even when data were analyzed in the mixed-model. This analysis showed a difference among the tests in relation to eggs viability, which was higher in test 2 than in test 1 (Table 3). These findings indicate that while cultivars may differ in their attractiveness to adults with respect to feeding and shelter, they do not significantly affect egg viability. Similar results were obtained by Garcia et al. (2011), who reported no significant differences in egg viability when $M$. fimbriolata nymphs and females were kept on different sug-

Table 3 - Viability of Mahanarva fimbriolata eggs on each cultivar in the free-choice tests.

\begin{tabular}{|c|c|c|c|c|}
\hline \multirow{2}{*}{ Cultivar } & \multicolumn{4}{|c|}{ Eggs viability (\%) } \\
\hline & test 1 & test 2 & test 3 & mean \\
\hline SP81-3250 & $41 \pm 13 a$ & $80 \pm 6 a$ & $48 \pm 14 a$ & $57 \pm 7 a$ \\
\hline IAC87-3396 & $41 \pm 20 a$ & $71 \pm 18 a$ & $64 \pm 10 a$ & $59 \pm 9 a$ \\
\hline IAC91-1099 & $38 \pm 14 a$ & $88 \pm 5 a$ & $54 \pm 14 a$ & $60 \pm 9 a$ \\
\hline IACSP93-3046 & $54 \pm 17 a$ & $59 \pm 10 a$ & $70 \pm 9 a$ & $61 \pm 7 a$ \\
\hline IACSP95-1218 & $43 \pm 16 a$ & $78 \pm 5 a$ & $68 \pm 8 a$ & $63 \pm 7 a$ \\
\hline IACSP95-3028 & $43 \pm 17 a$ & $72 \pm 9 a$ & $77 \pm 11 \mathrm{a}$ & $63 \pm 8 a$ \\
\hline IACSP96-3060 & $40 \pm 12 \mathrm{a}$ & $78 \pm 9 a$ & $70 \pm 15 a$ & $63 \pm 9 a$ \\
\hline IACSP94-4004 & $56 \pm 19 a$ & $67 \pm 15 a$ & $71 \pm 12 \mathrm{a}$ & $65 \pm 8 a$ \\
\hline IACSP94-2101 & $65 \pm 12 a$ & $56 \pm 16 a$ & $78 \pm 7 a$ & $66 \pm 7 a$ \\
\hline IACSP94-2094 & $55 \pm 12 \mathrm{a}$ & $83 \pm 3 a$ & $58 \pm 16 a$ & $66 \pm 7 a$ \\
\hline IACSP96-2042 & $54 \pm 14 a$ & $82 \pm 13 a$ & $64 \pm 15 a$ & $67 \pm 7 a$ \\
\hline IACSP95-5000 & $61 \pm 16 \mathrm{a}$ & $84 \pm 5 a$ & $61 \pm 18 a$ & $69 \pm 8 \mathrm{a}$ \\
\hline \multicolumn{5}{|c|}{$\overline{F \text { values (degree of freedom) }}$} \\
\hline Cultivar & $0.37^{\mathrm{NS}}(11)$ & $0.76^{\mathrm{NS}}(11)$ & $0.46^{\mathrm{NS}}(11)$ & $0.28^{\mathrm{NS}}(11)$ \\
\hline Test & - & - & - & $10.91^{* *}(2)$ \\
\hline Cultivar $\times$ test & - & - & - & $0.89^{\mathrm{NS}}(22)$ \\
\hline CV (\%) & 36 & 29 & 30 & 29 \\
\hline
\end{tabular}

Means in the same column followed by the same letter do not differ significantly (t test, $p<0.05$ ); NS and **indicate values not significant and significant at $p \leq 0.01$ respectively. arcane cultivars. The mean viability varied from $57 \pm 7$ (SP81-3250) to $69 \pm 8 \%$ (IACSP95-5000). These values are lower than those reported by Garcia et al. (2006) and similar to those reported by Garcia et al. (2011), which were also determined using sugarcane cultivars and $M$. fimbriolata.

Cultivar IACSP96-2042 received the least eggs in the no-choice oviposition-preference studies and cultivars IAC91-1099 and IACSP95-5000 received most eggs (Table 4). These findings suggest that genotype of the plant on which adults are kept influences female fecundity. Such differences in $M$. fimbriolata female fecundity relative to the sugarcane cultivars on which they were kept were also reported by Garcia et al. (2011).

Nymph emergence ceased from March onward, although portions of the eggs were kept under BOD conditions, most likely because the eggs entered the diapause phase.

In diapause eggs, the normal embryo activities are controlled by neurohormonal factors and conditioned to the perception of environmental signals (Tauber et al., 1986). Diapause eggs are laid throughout the rainy season at different proportions. At the beginning of the rainy season, when pest infestation is still low, the proportion of diapause eggs is low and the vast majority consists of non-diapause eggs. The proportion of diapause eggs tends to increase as population increases in the second and third generations of the pest, at the end of the rainy season (Sujii et al., 1995). Unlike non-diapause eggs, diapause eggs do not develop even under favorable conditions of moisture and temperature, until the period of diapause is complete (Beck, 1980). There are no visible morphological differences between non-diapause and diapause eggs, and diapause is maternally determined (Saunders, 1987). Since the experiment to determine ovi-

Table 4 - Numbers of Mahanarva fimbriolata eggs found on each cultivar in the no-choice tests.

\begin{tabular}{lc}
\hline Cultivar & Eggs per plant \\
\hline IACSP96-2042 & $39.6 \pm 14.9 \mathrm{a}$ \\
IACSP94-2101 & $93.4 \pm 17.1 \mathrm{~b}$ \\
IACSP96-3060 & $94.0 \pm 24.4 \mathrm{~b}$ \\
IACSP94-4004 & $95.7 \pm 36.3 \mathrm{bc}$ \\
IACSP95-3028 & $100.1 \pm 26.3 \mathrm{bc}$ \\
SP81-3250 & $106.9 \pm 29.9 \mathrm{bc}$ \\
IACSP94-2094 & $113.9 \pm 14.8 \mathrm{bc}$ \\
IACSP95-1218 & $115.1 \pm 29.2 \mathrm{bc}$ \\
IAC87-3396 & $127.7 \pm 35.6 \mathrm{bc}$ \\
IACSP95-5000 & $149.1 \pm 30.6 \mathrm{~cd}$ \\
IACSP93-3046 & $154.3 \pm 52.2 \mathrm{~cd}$ \\
IAC91-1099 & $230.6 \pm 43.5 \mathrm{~d}$ \\
\hline F values (degree of freedom) & \\
Block & $29.10^{* *}(6)$ \\
Cultivar & $6.36^{* *}(11)$ \\
\hline CV (\%) & 14
\end{tabular}

Means in the same column followed by the same letter do not differ significantly (t test, $p<0.05$ ); ${ }^{* *}$ indicate values significant at $p \leq 0.01$. 
position preferences of $M$. fimbriolata in no-choice test was conducted during Jan and Feb, when the pest was in its second or third generation in the field and laboratory, the rate of diapause eggs was high and it was not possible to evaluate egg viability in this experiment.

Cultivars IACSP96-2042, IACSP96-3060 and IACSP94-2101 received the least eggs during the free-choice and no-choice oviposition-preference studies, suggesting that they have some level of antixenosis resistance. According to Lara (1991), plants with a higher resistance level should show similar patterns in both types of experiments, given that they are kept under similar infestation conditions. This hypothesis is consistent with our findings in the present study.

No-choice tests are of great practical value, as large areas of croplands are often planted with only a single cultivar, thus giving insects no choice between different plant types (Lourenção and Yuki, 1982). This is especially true for sugarcane in Brazil, where single cultivars often cover extensive and continuous areas in the regions where they are cultivated. Therefore, planting cultivars that receive relatively fewer eggs, such as IACSP96-2042, IACSP96-3060 and IACSP94-2101, could significantly reduce pest populations in the field.

In the no-choice and free-choice tests, cultivar SP81-3250, which was used as a standard, showed intermediate oviposition values. This cultivar was not significantly different from the others in terms of the number of eggs received. Cultivars IACSP95-1218 and IACSP94-2094 were preferred during the free-choice oviposition-preference test, whereas the preferred cultivars during the no-choice test were IAC91-1099, IACSP93-3046, IACSP95-5000 and IAC87-3396, although these were not significantly different from cultivars IACSP95-1218 and IACSP94-2094. These results suggest that although spittlebugs may prefer certain cultivars to others for feeding and egg laying, these insects can maintain their reproductive capacity on intermediate or neutral cultivars if no other option is given.

Differences between the cultivars were more pronounced in the no-choice test than in the free-choice one. In the no-choice test, the least preferred cultivar (IACSP96-2042) received 3.2- to 5.8-fold fewer eggs than the most preferred cultivars (IAC91-1099, IACSP93-3046, IACSP95-5000 and IAC87-3396). On the other hand, the least preferred cultivar (IACSP96-3060) in the free-choice test received only 2.3- to 2.5-fold fewer eggs than the most preferred cultivars (IACSP95-1218 and IACSP94-2094). These data suggest that adults tend to distribute their eggs among several different preferred or intermediate cultivars under free-choice conditions, avoiding only non-preferred cultivars.

In the test used to determine the effects of different cultivars on nymph development, nymph survival was significantly smaller for cultivars IACSP96-2042 and IAC91-1099 compared with cultivars IACSP94-2101, IACSP95-5000, IACSP95-3028 and SP81-3250 (Table 5). The mixed-model analysis showed a significant estimate value only for IAC91-1099 cultivar (estimate $=-0.3699 ; \mathrm{t}$ value $=-2.91, p=0.0064)$. Thus, according to this analysis, only in IAC91-1099 cultivar, nymph survival was significantly different from the average of all cultivars. No correlations were observed between cultivar and nymph stage duration (Table 5), even when the mixedmodel analysis was carried out. These results indicate the existence of different antibiosis levels for $M$. fimbriolata among the various cultivars tested, with cultivars IACSP96-2042 and IAC91-1099 showing the highest antibiosis levels.

Different antibiosis levels for spittlebugs have been observed by researchers in many cultivated plant species (e.g., Auad et al., 2007; Cardona et al., 2004; Lapointe et al., 1992; López et al., 2009; Miles et al., 2006; Pabón et al., 2007 and Panda and Heinrichs, 1983), although little information was available for sugarcane genotypes prior to this study. One of the few studies involving sugarcane did report significant effects for six sugarcane cultivars on $M$. fimbriolata nymph survival (Garcia et al., 2011) and reported nymph survival values were similar to those in this study (78 \% for SP81-3250). However, in contrast to the findings of this study, Garcia et al. (2011) stated that nymph stage duration varied significantly depending on the cultivar on which the nymphs were fed.

Dinardo-Miranda et al. (2014) also reported different antibiosis levels for $M$. fimbriolata in sugarcane cultivars in which nymph survival varied from $47.9 \%$ for IACSP97-7586 to $84.5 \%$ for IACSP97-2098.

According to Cardona et al. (1999), cultivars for which nymph survival is greater than $50 \%$ are considered susceptible, whereas cultivars for which this value is less than $30 \%$ are considered resistant. Other cultivars (i.e., those showing 31 to $50 \%$ survival) are considered

Table 5 - Nymph survival (\%) and nymph stage duration (days) on the sugarcane cultivars.

\begin{tabular}{lcc}
\hline Cultivar & Nymph survival (\%) & Nymph stage duration (days) \\
\hline IAC91-1099 & $20 \pm 12 \mathrm{a}$ & $41 \pm 1 \mathrm{a}$ \\
IACSP96-2042 & $33 \pm 7 \mathrm{ab}$ & $43 \pm 1 \mathrm{a}$ \\
IACSP94-2094 & $40 \pm 12 \mathrm{abc}$ & $40 \pm 3 \mathrm{a}$ \\
IACSP95-1218 & $40 \pm 6 \mathrm{abc}$ & $43 \pm 1 \mathrm{a}$ \\
IACSP94-4004 & $58 \pm 10 \mathrm{bcd}$ & $41 \pm 2 \mathrm{a}$ \\
IAC87-3396 & $58 \pm 17 \mathrm{bcd}$ & $42 \pm 1 \mathrm{a}$ \\
IACSP96-3060 & $63 \pm 9 \mathrm{~cd}$ & $41 \pm 2 \mathrm{a}$ \\
IACSP93-3046 & $65 \pm 9 \mathrm{~cd}$ & $43 \pm 2 \mathrm{a}$ \\
IACSP95-3028 & $73 \pm 11 \mathrm{~cd}$ & $39 \pm 1 \mathrm{a}$ \\
IACSP95-5000 & $78 \pm 9 \mathrm{~d}$ & $41 \pm 2 \mathrm{a}$ \\
SP81-3250 & $78 \pm 9 \mathrm{~d}$ & $41 \pm 2 \mathrm{a}$ \\
IACSP94-2101 & $83 \pm 5 \mathrm{~d}$ & $41 \pm 3 \mathrm{a}$ \\
\hline F values (degree of freedom) & $0.56^{\text {NS }}$ (11) \\
Cultivar & $3.35^{* *}$ (11) \\
CV (\%) & 32 \\
\hline \\
Means in the same column followed by the same letter do not differ significantly \\
(t test, $p<0.05$; NS and * *indicate values not significant and significant at \\
$p \leq 0.01$ respectively.
\end{tabular}


intermediate. Based on these thresholds, cultivar IAC911099 is resistant, cultivars IACSP95-1218, IACSP94-2094 and IACSP96-2042 are intermediate and all other tested cultivars are susceptible.

The antibiosis and antixenosis characteristics of plants are important factors in pest-reduction strategies, which is especially true for large cultivated areas with pest-resistant cultivars (Lara, 1991). The multiplication rate (MR) values estimated in this study may reflect more accurately the effect of cultivar type on spittlebug populations under field conditions, as they incorporate both antibiosis and antixenosis effects. Oviposition data from the no-choice test were used to estimate MR values, as this test is more similar to the conditions found in most Brazilian sugarcane fields, which are typically large areas planted with only a single cultivar, thus, providing no options for the insects. Calculations were performed using egg viability $63 \%$, which was the average value obtained from the free-choice oviposition-preference test. This value was used because it was not possible to obtain egg-viability data from the no-choice test and because the cultivar type did not significantly influence egg viability during the free-choice test. $M$. fimbriolata multiplication rates varied from 1.4 for cultivar IACSP96-2042 to 12.1 for IACSP95-5000 (Table 6). Therefore, spittlebug populations tend to be smaller in sugarcane plantations growing cultivar IACSP96-2042 than plantations growing cultivar IACSP95-5000.

Despite being one of the most preferred cultivars for oviposition during the no-choice test, spittlebug MR for cultivar IAC91-1099 (4.8) was similar to the rates for cultivars IACSP94-2094 (4.8) and IACSP95-1218 (4.8) and smaller than the rates for most tested cultivars, including standard SP81-3250 (8.7) (Table 6). These findings suggest that sugarcane fields planted with genotypes IACSP94-2094 and IACSP95-1218 tend to have smaller spittlebug populations than those planted with one of the other cultivars tested.

In the tolerance study, differences in chlorophyll content were observed between the leaves from plots in-

Table 6 - Multiplication rate of Mahanarva fimbriolata for each cultivar.

\begin{tabular}{lc}
\hline Cultivar & Multiplication rate \\
\hline IACSP96-2042 & 1.4 \\
IAC91-1099 & 4.5 \\
IACSP94-2094 & 4.8 \\
IACSP95-1218 & 4.8 \\
IACSP94-4004 & 5.8 \\
IACSP96-3060 & 6.2 \\
IACSP95-3028 & 7.6 \\
IAC87-3396 & 7.7 \\
IACSP94-2101 & 8.1 \\
SP81-3250 & 8.7 \\
IACSP93-3046 & 10.5 \\
IACSP95-5000 & 12.1 \\
\hline
\end{tabular}

fested with spittlebugs and those that were not infested (Table 7). Infested plots showed on average $44 \%$ less leaf chlorophyll than uninfested plots did. Many researchers have observed reductions in chlorophyll content due to pest attack (Flinn et al., 2001; Boina et al., 2005; DiazMontano et al., 2007; López et al., 2009). These authors agree that susceptible plant cultivars tend to show greater reductions in chlorophyll levels than tolerant cultivars do when attacked by pests (Flinn et al., 2001; Boina et al., 2005; Diaz-Montano et al., 2007; López et al., 2009). For example, Resende et al. (2012) recorded a reduction of up to $81 \%$ in chlorophyll levels in Brachiaria ruziziensis due to attack by $M$. spectabilis adults. According to these authors, toxic saliva injected into the leaves by adults interferes with photosynthetic activity. The data presented here indicate that nymphs feeding on roots can also cause reductions in leaf chlorophyll content.

A study conducted by Dinardo-Miranda et al. (2014) showed that spittlebugs can reduce leaf chlorophyll content in sugarcane and, therefore, photosynthetic rate and plant production decrease. In this study, all cultivars, with the exception of IACSP94-2094, showed reductions in aboveground biomass due to spittlebug attack (Table 7). On average, $M$. fimbriolata-infested plots showed loss of $45 \%$ of aboveground biomass compared with uninfested plots (Table 7).

Despite a significant reduction in chlorophyll content due to spittlebug attack, cultivar IACSP94-2094 showed a decrease in aboveground biomass of only $11 \pm$ $5 \%$, value not significant and lower than that obtained for SP81-3250 (37 $\pm 9 \%)$, the susceptibility standard (Table 8). Thus, IACSP94-2094 may have some degree of tolerance to this pest species. The other cultivars showed aboveground biomass reductions ranging from $36 \pm$ $10 \%$ (IACSP96-2042) to $85 \pm 3 \%$ (IACSP95-1218) and should be considered more susceptible to spittlebugs than SP81-3250 (Table 8).

The use of tolerant cultivars is an important tool in pest-management strategies (Painter, 1951; Panda and Khush, 1985; Smith, 2005). The development of pest-insect biotypes that can break host resistance is less likely when tolerant cultivars are used because pest populations are kept at high levels. Indeed, the opposite is true for plant cultivars that show antibiosis or antixenosis resistance. Nevertheless, many researchers agree that there is significant risk when tolerant cultivars to spittlebug are cultivated across large and continuous areas (Cardona et al., 2004; Lapointe et al., 1992). For example, growing tolerant cultivars in humid tropics of Brazil could favor the growth of spittlebug populations to such a high degree that they could break tolerance and cause severe crop damage, even in tolerant cultivars (Cardona et al., 2004). This scenario would be especially dangerous in Brazil regarding sugarcane, where this crop is cultivated in large continuous areas. Therefore, it would be interesting to cultivate sugarcane cultivars with a variety of associated resistance mechanisms, even if they are only at moderate or low 
Table 7 - Relative values of chlorophyll content (determined in +1 leaf using a chlorophyll meter) and aboveground biomass weight (g) for each cultivar, both infested and non-infested with spittlebugs.

\begin{tabular}{|c|c|c|c|c|}
\hline \multirow{2}{*}{ Cultivar } & \multicolumn{2}{|c|}{ Relative values of chlorophyll content in +1 leaf } & \multicolumn{2}{|c|}{ Aboveground biomass weight (g) } \\
\hline & Infested & Non-infested & Infested & Non-infested \\
\hline IAC87-3396 & $23.7 \pm 4.5 \mathrm{a}$ & $44.6 \pm 3.6 b$ & $25.5 \pm 3.4 \mathrm{a}$ & $56.4 \pm 3.4 b$ \\
\hline IAC91-1099 & $31.1 \pm 4.2 \mathrm{a}$ & $49.1 \pm 1.6 b$ & $29.1 \pm 4.4 \mathrm{a}$ & $61.8 \pm 5.2 b$ \\
\hline IACSP93-3046 & $26.9 \pm 4.2 \mathrm{a}$ & $50.8 \pm 3.0 b$ & $30.8 \pm 4.7 \mathrm{a}$ & $49.7 \pm 2.9 b$ \\
\hline IACSP94-2101 & $24.8 \pm 3.8 \mathrm{a}$ & $39.0 \pm 3.4 b$ & $20.1 \pm 4.2 \mathrm{a}$ & $50.6 \pm 3.5 b$ \\
\hline IACSP94-2094 & $33.6 \pm 4.7 \mathrm{a}$ & $52.1 \pm 1.5 b$ & $55.1 \pm 4.4 \mathrm{a}$ & $61.9 \pm 5.2 \mathrm{a}$ \\
\hline IACSP94-4004 & $25.1 \pm 4.8 \mathrm{a}$ & $41.0 \pm 3.0 b$ & $35.5 \pm 2.1 \mathrm{a}$ & $64.8 \pm 4.7 b$ \\
\hline IACSP95-1218 & $5.3 \pm 2.5 \mathrm{a}$ & $38.3 \pm 4.5 b$ & $6.5 \pm 1.5 \mathrm{a}$ & $44.3 \pm 3.1 b$ \\
\hline IACSP95-3028 & $24.6 \pm 4.2 \mathrm{a}$ & $44.8 \pm 2.3 b$ & $23.6 \pm 2.4 \mathrm{a}$ & $48.5 \pm 5.3 b$ \\
\hline IACSP95-5000 & $22.8 \pm 4.2 \mathrm{a}$ & $47.2 \pm 2.5 b$ & $29.8 \pm 5.5 a$ & $53.8 \pm 1.1 b$ \\
\hline IACSP96-2042 & $27.1 \pm 2.2 \mathrm{a}$ & $42.4 \pm 3.2 b$ & $28.4 \pm 5.2 \mathrm{a}$ & $44.2 \pm 2.2 b$ \\
\hline IACSP96-3060 & $28.7 \pm 2.6 \mathrm{a}$ & $46.1 \pm 1.9 b$ & $50.9 \pm 3.0 \mathrm{a}$ & $86.0 \pm 4.9 b$ \\
\hline SP81-3250 & $25.8 \pm 3.8 \mathrm{a}$ & $40.4 \pm 4.3 b$ & $36.5 \pm 5.0 \mathrm{a}$ & $58.1 \pm 4.8 b$ \\
\hline
\end{tabular}

$F$ values (degree of freedom)

\begin{tabular}{lcc} 
Cultivar & $5.14^{* *}(11)$ & $18.13^{* *}(11)$ \\
Infestation & $182.89^{* *}(1)$ & $231.95^{* *}(1)$ \\
Cultivar $\times$ infestation & $1.34^{\text {NS }}(11)$ & $2.73^{*}(11)$ \\
\hline
\end{tabular}

Cultivar $\times$ infestation

CV (\%)

24

20

Means within the same cultivar and same parameter followed by the same letter are not significantly different (t test, $p \leq 0.05) .{ }^{\text {Ns }},{ }^{*}$ and ${ }^{* *}$ indicate values not significant, significant at $p \leq 0.05$ and significant at $p \leq 0.01$ respectively.

Table 8 - Reduction (\%) in relative values of chlorophyll content in +1 leaf and on aboveground biomass weight due to Mahanarva fimbriolata infestation on each cultivar.

\begin{tabular}{lcc}
\hline Cultivar & $\begin{array}{c}\text { Relative values of } \\
\text { chlorophyll content in }+1 \text { leaf }\end{array}$ & $\begin{array}{c}\text { Aboveground } \\
\text { biomass weight }\end{array}$ \\
\hline IACSP94-2094 & $36 \pm 9 \mathrm{a}$ & $11 \pm 5 \mathrm{a}$ \\
IACSP96-2042 & $36 \pm 8 \mathrm{a}$ & $36 \pm 10 \mathrm{~b}$ \\
SP81-3250 & $36 \pm 7 \mathrm{a}$ & $37 \pm 9 \mathrm{~b}$ \\
IACSP93-3046 & $42 \pm 10 \mathrm{a}$ & $38 \pm 7 \mathrm{bc}$ \\
IACSP96-3060 & $38 \pm 7 \mathrm{a}$ & $41 \pm 5 \mathrm{bc}$ \\
IACSP94-4004 & $39 \pm 11 \mathrm{a}$ & $45 \pm 4 \mathrm{bc}$ \\
IACSP95-5000 & $52 \pm 7 \mathrm{a}$ & $45 \pm 10 \mathrm{bc}$ \\
IACSP95-3028 & $45 \pm 10 \mathrm{a}$ & $51 \pm 8 \mathrm{bc}$ \\
IAC91-1099 & $37 \pm 9 \mathrm{a}$ & $53 \pm 6 \mathrm{bc}$ \\
IAC87-3396 & $47 \pm 8 \mathrm{a}$ & $55 \pm 6 \mathrm{bc}$ \\
IACSP94-2101 & $36 \pm 13 \mathrm{a}$ & $60 \pm 9 \mathrm{c}$ \\
IACSP95-1218 & $86 \pm 6 \mathrm{~b}$ & $85 \pm 3 \mathrm{~d}$ \\
\hline F values (degree of freedom) & & \\
Cultivar & $3.48^{* *}$ & 30 \\
\hline CV (\%) & 35 & $30 *$ \\
\hline
\end{tabular}

Means within the same column followed by the same letter are not significantly different ( $t$ test, $p \leq 0.05) .{ }^{* *}$ indicate values significant at $p \leq 0.01$.

levels. Modeling studies indicate that low or moderate antixenosis, antibiosis and tolerance levels may be effective for pest control (Kennedy et al., 1987). According to this study, IACSP94-2094 appears to be one of the most promising cultivars for planting in infested areas, as it shows antixenosis, antibiosis and tolerance characteristics. Cultivar IACSP96-2042 could also be an interesting choice for planting in infested areas due to its high levels of antixenosis and antibiosis.

\section{Acknowledgments}

To FAPESP - São Paulo State Foundation for Research Support, for financial support to the research project 2011/08458-0.

\section{References}

Auad, A.M.; Simões, A.D.; Pereira, A.V.; Braga, A.L.F.; Souza Sobrinho, F.; Ledo, F.J.S.; Paula-Moraes, S.V.; Oliveira, A.S.; Ferreira, R.B. 2007. Selection of elephant grass genotypes resistance to spittlebug. Pesquisa Agropecuária Brasileira 42:1077-1081 (in Portuguese, with abstract in English).

Beck, S.D. 1980. Insect Photoperiodism. 2ed. Academic Press, New York, NY, USA.

Boina, D.; Prabhakar, S.; Smith, C.M.; Starley, S.; Zhu, L.; Boyko, E.; Reese, J.C. 2005. Categories of resistance to biotype I greenbugs (Homoptera: Aphididae) in wheat lines containing the greenbug resistance genes $G b x$ and Gby. Journal of Kansas Entomological Society 78: 252-260.

Cardona, C.; Miles, J.W.; Sotelo, G. 1999. An improved methodology for massive screening of Brachiaria spp. Genotypes for resistance to Aenolamia varia (Homoptera: Cercopidae). Journal of Economic Entomology 92: 490-496.

Cardona, C.; Fory, P.; Sotelo, G.; Pabón, A.; Diaz, G.; Miles, J.W. 2004. Antibiosis and tolerance to five species of spittlebug (Homoptera: Cercopidae) in Brachiaria spp.: implications for breeding for resistance. Journal of Economic Entomology 97: 635-645.

Cruz, L.P.; Baldin, E.L.L.; Castro, M.J.P.; Fanela, T.L.M.; Silva, P.H.S. 2012. Attractiveness of cowpea genotypes for Bemisia tabaci B-biotype oviposition. Pesquisa Agropecuária Brasileira 47: 1563-1571 (in Portuguese, with abstract in English). 
Diaz-Montano, J.; Reese, J.C.; Schapaugh, W.T.; Campbell, L.R. 2007. Chrorophyll loss caused by soybean aphid (Hemipetra: Aphididae) feeding soybean. Journal of Economic Entomology 100: 1657-1662.

Dinardo-Miranda, L.L.; Costa, V.P.; Fracasso, J.V.; Perecin, D.; Oliveira, M.C.; Izeppi, T.S.; Lopes, D.O.P. 2014. Resistance of sugarcane cultivars to Mahanarva fimbriolata (Stål) (Hemiptera: Cercopidae). Neotropical Entomology 43:90-95.

Dinardo-Miranda, L.L.; Ferreira, J.M.G.; Carvalho, P.A.M. 2001. Effect of harvest period and sugarcane variety on Mahanarva fimbriolata (Stål) (Hemiptera: Cercopidae) infestation. Neotropical Entomology 30: 145-149 (in Portuguese, with abstract in English).

Dinardo-Miranda, L.L.; Figueiredo, P.; Landell, M.G.A.; Ferreira, J.M.G.; Carvalho, P.A.M. 1999. Damage caused by spittlebug (Mahanarva fimbriolata) to several sugarcane genotypes. STAB - Açúcar, Álcool e Subprodutos 17: 48-52 (in Portuguese, with abstract in English).

Dinardo-Miranda, L.L.; Fracasso, J.V. 2013. Sugarcane straw and the populations of pests and nematodes. Scientia Agricola 70: 305-310.

Dinardo-Miranda, L.L.; Garcia, V.; Parazzi, J.V. 2002. Effect of insecticides on Mahanarva fimbriolata (Stål) (Hemiptera: Cercopidae) and fitoparasitic nematodes control, on technological quality and sugarcane yield. Neotropical Entomology 31: 609-614 (in Portuguese, with abstract in English).

Dinardo-Miranda, L.L.; Gil, M.A. 2007. Assessment of the economic injury level of Mahanarva fimbriolata (Stål) (Hemiptera: Cercopidae) to sugarcane. Bragantia 66: 81-88 (in Portuguese, with abstract in English).

Dinardo-Miranda, L.L.; Pivetta, J.P.; Fracasso, J.V. 2008. Economic injury level for sugarcane caused by the spittlebug Mahanarva fimbriolata (Stål) (Hemiptera: Cercopidae). Scientia Agricola 65: 16-24.

Dinardo-Miranda, L.L.; Vasconcelos, A.C.M.; Ferreira, J.M.G.; Garcia Jr., C.A.; Coelho, A.L.; Gil, M.A. 2004. Efficiency of Metarhizium anisopliae (Metsch) on sugarcane root froghopper Mahanarva fimbriolata (Stål) (Hemiptera: Cercopidae). Neotropical Entomology 33: 743-749 (in Portuguese, with abstract in English).

Dinardo-Miranda, L.L.; Vasconcelos, A.C.M.; Vieira, S.R.; Fracasso, J.V.; Grego, C.R. 2007. Use of geostatistics to evaluate Mahanarva fimbriolata (Stål) (Hemiptera: Cercopidae) spatial distribution on sugarcane. Bragantia 66: 449-455 (in Portuguese, with abstract in English).

Flinn, M.; Smith, C.M.; Reese, J.C.; Gill, B. 2001. Categories of resistance to greenbug (Homoptera: Aphididae) biotype I in Aegilops tauschii germoplasm. Journal of Economic Entomology 94: 555-563.

Garcia, J.F.; Botelho, P.S.M.; Parra, J.R.P. 2006. Biology and fertility life table of Mahanarva fimbriolata (Stål) (Hemiptera: Cercopidae) in sugarcane. Scientia Agricola 63: 317-320.

Garcia, J.F.; Botelho, P.S.M.; Parra, J.R.P. 2007. Laboratory rearing technique of Mahanarva fimbriolata (Stål) (Hemiptera: Cercopidae). Scientia Agricola 64: 73-76.
Garcia, J.F.; Prado, S.S.; Vendramim, J.D.; Botelho, O.S. 2011. Effect of sugarcane varieties on the development of Mahanarva fimbriolata (Hemiptera: Cercopidae). Revista Colombiana de Entomologia 37: 16-20.

Kennedy, G.G.; Gould, F.; Deponti, O.M.B.; Stinner, R.E. 1987. Ecological, agricultural, genetic, and commercial considerations in the deployment of insect-resistant germplasm. Environmental Entomology 16: 327-338.

Lapointe, S.L.; Serrano, M.S.; Arango, G.L.; Sotelo, G.; Córdoba, F. 1992. Antibiosis to spittlebugs (Homoptera: Cercopidae) in accessions of Brachiaria spp. Journal of Economic Entomology 85: 1485-1490.

Lara, F.M. 1991. Principles of Plant Resistance to Insects $=$ Princípios da Resistência de Plantas a Insetos. 2ed. Ícone, São Paulo, SP, Brazil (in Portuguese).

Lourenção, A.L.; Yuki, V.A. 1982. Bemisia tabaci (Genn) (Homoptera: Aleyrodidae) oviposition on three soybean varieties in a non-choice type experiment. Bragantia 41: 199202 (in Portuguese, with abstract in English).

López, F.; Cardona, C.; Miles, J.W.; Sotelo, G.; Montoya, J. 2009. Screening for resistance to adult spittlebugs (Hemiptera: Cercopidae) in Brachiaria spp.: methods and categories of resistance. Journal of Economic Entomology 102: 1309-1316.

Madaleno, L.L.; Raveli, G.C.; Presotti, L.E.; Mutton, M.A.; Fernandes, O.; Mutton, M.J.R. 2008. Influence of Mahanarva fimbriolata (Stål) (Hemiptera: Cercopidae) injury on the quality of sugarcane juice. Neotropical Entomology 37: 6873.

Miles, J.W.; Cardona, C.; Sotelo, G. 2006. Recurrent selection in a synthetic Brachiaria grass population improves resistance to three spittlebug species. Crop Science 46: 1088-1093.

Oriani, M.A.; Vendramin, J.D.; Brunherotto, R. 2005. Atractiveness and oviposition nonpreference of Bemisia tabaci (Genn.) Biotype B (Hemiptera: Aleyrodidae) for bean genotypes. Neotropical Entomology 34: 105-111 (in Portuguese, with abstract in English).

Pabón, A.; Cardona, C.; Miles, J.W.; Sotelo, G. 2007. Response of resistant and susceptible Brachiaria spp. genotypes to simultaneous infestation with multiple species of spittlebugs (Hemiptera: Cercopidae). Journal of Economic Entomology 100: 1896-1903.

Painter, H. 1951. Insect Resistance in Crop Plants. Macmillan, New York, NY, USA.

Panda, N.; Heinrichs, E.A. 1983. Levels of tolerance and antibiosis in rice varieties having moderate resistance to the brown planthopper Nilaparvata lugens (Stal) (Hemiptera: Delphacidae). Environmental Entomology 12: 1204-1214.

Panda, N.; Khush, G.S. 1985. Host Plant Resistance to Insects. CAB International, Wallingford, UK.

Resende, T.T.; Auad, A.M.; Fonseca, M.G.; Santos, T.H.; Vieira, T.M. 2012. Impact of the spittlebug Mahanarva spectabilis on signal grass. The Scientific World Journal 2012. Available at: http://www.hindawi.com/journals/tswj/2012/926715/ [Accessed Aug 20, 2013]

Saunders, D.S. 1987. Photoperiodism and the hormonal control of insect diapauses. Science Progress 71: 1-69. 
Shortman, S.L.; Braman, S.K.; Duncan, R.R.; Hanna, W.W.; Engelke, M.C. 2002. Evaluation of turf grass species and cultivars for potential resistance to two lined spittlebug (Hemiptera: Cercopidae). Journal of Economic Entomology 95: 478-486.

Smith, C.M. 2005. Plant Resistance to Arthropods: Molecular and Conventional Approaches. Springer, Dordrecht, The Netherlands.

Sujii, E.R.; Garcia, M.A.; Fontes, E.M.G.; Carvalho, V. 1995. Effect of temperature and umidity under on the termination of diapause eggs and population density of the grass froghopper, Deois flavopicta (Stål) (Homoptera: Cercopidae). Anais da Sociedade Entomológica do Brasil 24: 465-478 (in Portuguese, with abstract in English).
Tauber, M.J.; Tauber, C.A.; Masaki, S. 1986. Seasonal Adaptations of Insects. Oxford University Press, New York, NY, USA.

Valle, G.E.; Lourenção, A.L. 2002. Resistance of soybean genotypes to Bemisia tabaci (Genn.) biotype B (Hemiptera: Aleyrodidae). Neotropical Entomology 31: 285-295 (in Portuguese, with abstract in English). 